\title{
Assessing the Effects of Climate Change on Inigation Water Requirement for Com in Zimbabwe
}

\author{
기후변화가 짐바브웨 옥수수 필요수량에 미치는 영향 평가 \\ Nkomozepi, Temba ${ }^{*}$ Chung, Sang-Ok ${ }^{*}+$ \\ 은코모제피 템바·정상옥
}

\begin{abstract}
기후변화는 피할 수 없으며 다음 세기에도 계속될 것이다. 이는 생태계와 토지와 물과 같은 자연자원의 이용에도 영향을 미칠 것이다. 연구 결과에 의하면 아프리카는 낮은 경제수준과 지역적 다양성으로 인하여 기후변화에 가장 취약한 지역 중의 하나이 다. 짐바브웨는 한계농지가 황폐화가 되는 등 농업분야가 특히 기후변화에 취약하다. 본 논문에서는 짐바브웨의 주요 옥수수 재 배지역에 대하여 기후변화가 옥수수의 필요수량에 미치는 영향을 공간적 및 시간적으로 분석하였다. 미래 기후예측은 HadCM3 전지구 모형 결과에 change factor를 곱하여 추정하였다. 배출가스 시나리오는 A2b 및 B2a를 선정하였고, 시간대는 2020s, 2050s 및 2080s 각각 30 년간에 대하여 분석하였다. 기준작물 증발산량은 Penman-Monteith 공식으로, 순관개량은 CROPWAT 모형을 이 용하여 구하였다. 순관개량의 공간적인 분석은 GIS를 이용하였다. 분석 결과 대상지역은 강우량이 감소하고 관개의 필요성이 크 게 증가할 것으로 나타났다. 2080s의 필요수량은 기준년도 (1961-1990)에 비하여 93 내지 $115 \%$ 증가할 것으로 예측되었다. 이 증가는 기온의 증가와 강우량의 감소에 기인한다. 대상 지역에 대한 기후변화 대응 전략 수립과 영향 저감대책에 대한 추가적인 연구가 필요하다고 하겠다.
\end{abstract}

Keywords: Climate change; corn; irrigation; zimbabwe

\section{Introduction}

Climate change projections and studies acknowledge that Africa will experience a warming trend over the 21st century, which is expected to be stronger than the global average. Most climate models agree on the spatial pattern of temperature change in Africa with the strongest warming in the Sahara and southern Africa. (Müller, 2009). Anthropogenic climate change could therefore lead to decreased water availability that will be exacerbated by increased water demand if the region becomes drier and warmer. Agricultural water use is likely to be the most influenced water use sector by climate change in Zimbabwe. Agriculture water withdrawals account for $79 \%$ of total water use in Zimbabwe. Agricultural water is used for

\footnotetext{
* Department of Agricultural Engineering, Kyungpook National University

$\dagger \quad$ Corresponding author Tel.: +82-53-950-5734

Fax: +82-53-950-6752

E-mail: sochung@knu.ac.kr

2010년 10월 13일 투고

2011년 1월 5일 심사완료

2011년 1월 7일 게재확정
}

irrigation, fish farming and livestock. Irrigated agriculture will continue to dominate the water demands for Zimbabwe in the foreseeable future. In one study, the Global irrigation model GIM (a module of WaterGap) was used to assess global net irrigation requirements using Hadley Centre Coupled Model, version 3 (HadCM3) output data and the assessment predicted an increase in net irrigation requirements by $4 \%$ and $1 \%$ for the 2020s and 2070s respectively for southern Africa (Doll, 2002). Maximum temperature increased by $1.2^{\circ} \mathrm{C}$ in 96 years (1897 to 1993) and mean total seasonal rainfall decreased by $10 \%$ in 94 years (1900 to 1994) (Unganai, 1996).

Corn (Zea mays L.) is the primary staple crop for $95 \%$ of Zimbabwe's population. Ambient temperature, precipitation and soil moisture as well as frequency of heat waves and drought are significant factors influencing corn production in southern Africa. Soil water is the most scarce essential plant input in southern Africa and according to Liebig's law of the minimum any reduction in water availability will directly aggravate the current crop situation. In Zimbabwe, research has predicted a $42 \%$ decrease in corn producing area and 
$25 \%$ shortening of the growing season in the future (Zhakata, 2004). Research on climate change impact on crop water use and yield has gained prominence for Zimbabwe. Earlier attempts carried out sensitivity analyses of regular evapotranspiration (ET) equations and/or crop simulation models to estimate climate scenarios based on projections of weather scenarios (e.g. Unganai, 1996; Makhado, 1996) and more recent attempts have used global circulation models(GCMs) as climate basis (e.g. Matarira et al., 2004)

Makhado (1996) predicted 11 to $17 \%$ corn yield reduction under irrigated conditions due to climate change using CERES Corn simulation model and 2 GCMs (Geophysical Fluid Dynamics Laboratory (GFDL) Model and the Canadian Climate Model (CGCM)). The reductions in corn yields were primarily attributed to ambient temperature increases which shorten the crop growth period, particularly the grain-filling period. Review of pertinent literatures revealed that the regional climatic impacts on the corn irrigation requirement in Zimbabwe have not been previously reported.

The objective of this research was therefore to assess the impacts of climate change on future net irrigation water requirements (IWR) under different climate scenarios for an intensive corn producing area covering three administrative provinces in the Northern part of Zimbabwe. Climate projections were derived from the HadCM3 (Gordon et al., 2000) and baseline climatology data, which was developed by the International Water Management Institute (IWMI) (New et al., 2002).

\section{MATERIAL AND METHODS}

\section{Study Area and Irrigated corn}

Zimbabwe is a landlocked country, located in southern Africa (latitude $15-22^{\circ}$ south and longitude $26-34^{\circ}$ east) and has a total area of $390,760 \mathrm{~km}^{2}$. The country is bordered by Zambia in the north, Mozambique in the east, South Africa in the south, and Botswana and Namibia in the west. $8.6 \%$ of the land area is cultivated land (FAO, 2005). Corn is the primary staple crop and usually occupies about $50 \%$ of the annual planted area. $63 \%$ of corn (by planted area) is grown under supplementary irrigation particularly in the large scale commercial areas (Musara et al., 2010). Corn production is increasingly coming under threat due to high temperature and low rainfall conditions. Zimbabwe, which is highly dependent on agricultural production sector, could see a rapid deterioration in the livelihood of the population as a result of climate change.

Climatic conditions in Zimbabwe are largely subtropical with one rainy season, from October to April, a cool winter season from April to August and the hottest and driest period from September to mid-November. Average annual

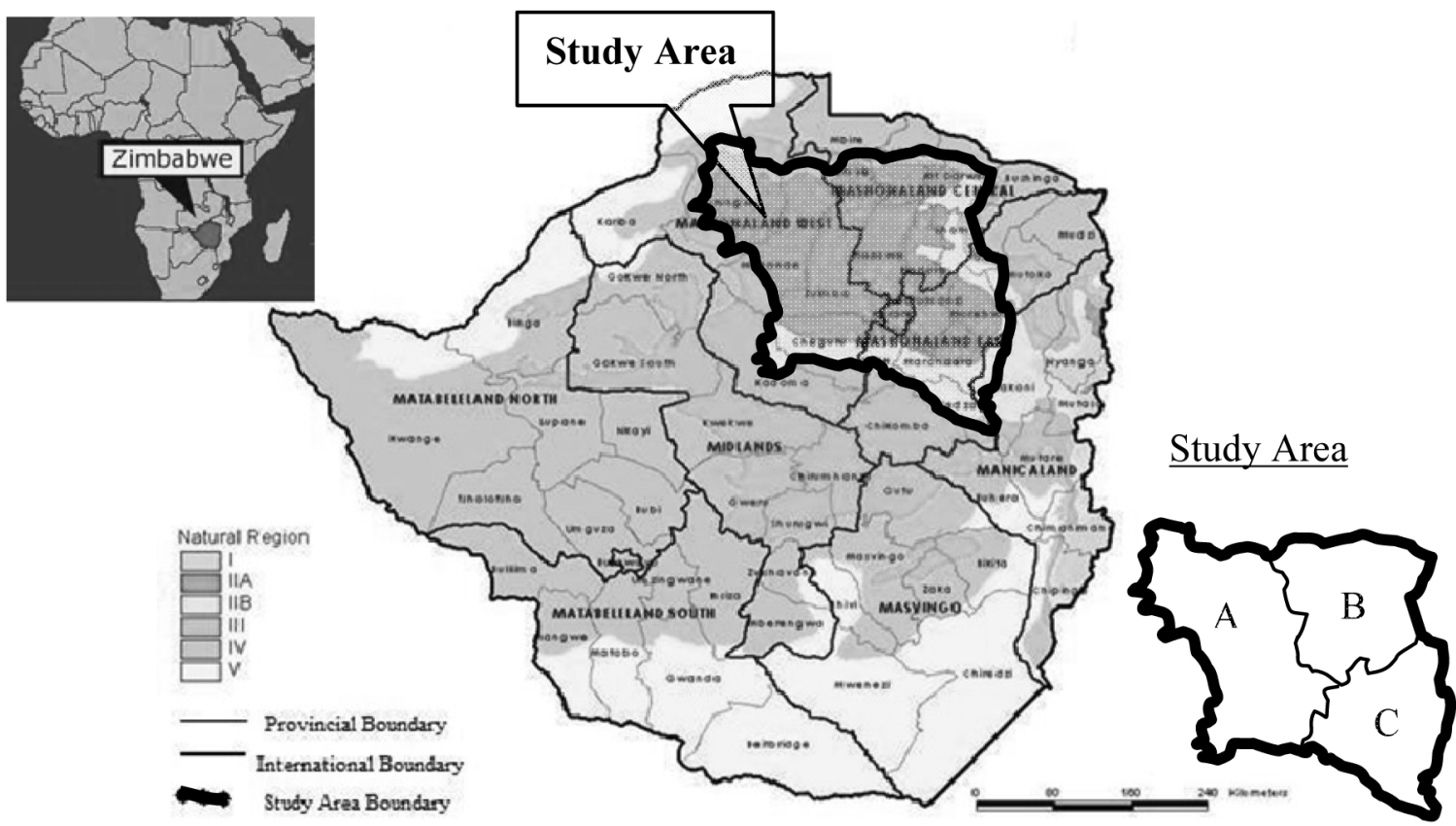

Fig. 1 Zimbabwe agro-ecological zones and the location map of the study area 
rainfall is $657 \mathrm{~mm}$, but ranges from over $1,000 \mathrm{~mm}$ in the eastern highlands to around $300-450 \mathrm{~mm}$ in the lowveldt in the south. Values of annual pan evaporation range from $1,400 \mathrm{~mm}$ in the eastern highlands up to $2,200 \mathrm{~mm}$ in the lowveldt. Only $37 \%$ of the country receives adequate rainfall for agriculture. The country is divided into five natural agro-ecological regions (NRs) which relate climate, soils and topography to appropriate farming systems. NR II is suitable for intensive cropping and livestock production and accounts for $75-80$ percent of the area planted to crops in Zimbabwe. This study will focus on NR II areas from which $75 \%$ of corn is produced in Zimbabwe covering 3 administrative provinces i.e. Mashonaland West (A), Central (B) and East (C) as shown in Fig. 1.

\section{Methodology}

In order to assess the impact of climate change on net IWR of the study area, an assessment methodology similar to previous studies e.g. Chung (2009a) was followed using the change factor method. This method involves 3 steps, first the establishment of long term baseline climatology data (1961-1990). Secondly, calculation of relative or absolute changes in the equivalent variable for the GCM grid box closest to the target site. Relative changes are used for rainfall, radiation, wind speed and relative humidity and absolute changes for temperature. Thirdly, the change suggested by the GCM for a particular time slice is applied to each monthly average in the baseline time series as shown in Fig. 2 (Diaz-Nieto and Wilby, 2005; Ahn et al., 2009).

A $10^{\prime}$ by $10^{\prime}$ latitude/longitude climate dataset assembled by IWMI from weather stations around the world for the period 1961-1990 was extracted and adopted as the baseline climatology for the study area. Change factors to the climate predicted by the HadCM3 were applied to an observed baseline for each pixel in the study catchment area to produce future projections. Climate projections from 30 year period time frames namely short-term 2010-2039 (2020s), mid-term 2040-2069 (2050s) and long-term 20702100 (2080s) are addressed.

Scenarios are coherent, internally consistent and plausible descriptions of a possible future state of the world. They are used to characterize the demographic, agricultural, energy, socio-economic and technological driving forces underlying anthropogenic greenhouse gas emissions which cause climate change. The IPCC developed four scenario families combining two sets of divergent tendencies: one set varying between strong economic values and strong environmental values, the other set between increasing globalization and increasing regionalization. The A2 scenario family describes a very heterogeneous world. The underlying theme is self-reliance and preservation of local identities. Fertility patterns across regions converge very slowly, which results in continuously increasing global population. Economic development is primarily regionally oriented and

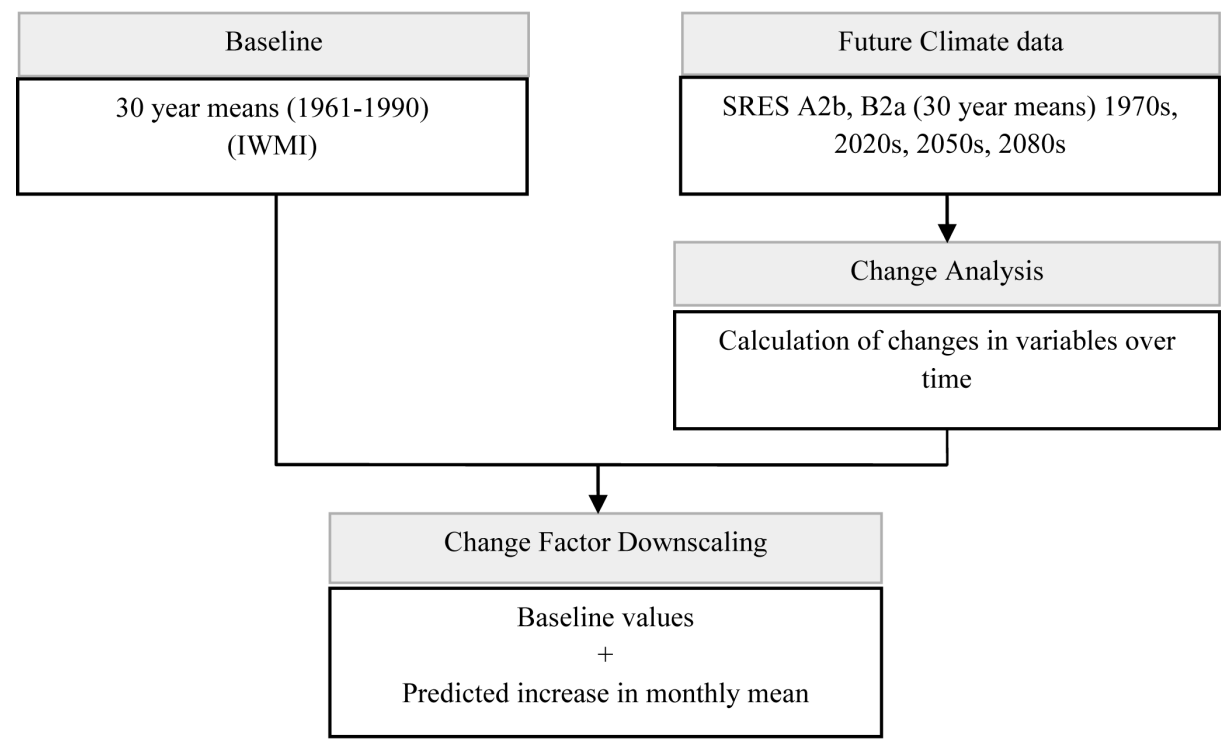

Fig. 2 Stages of the change factor method (modified from Ahn et al., 2009) 


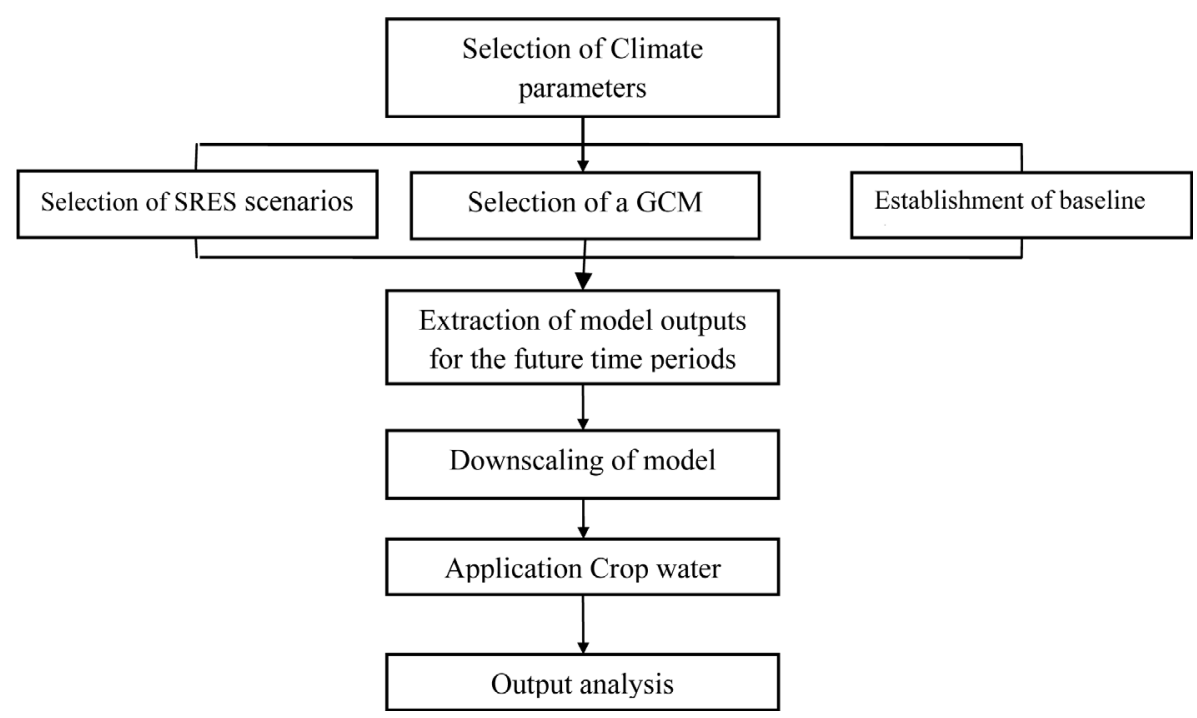

Fig. 3 Methodology flowchart

per capita economic growth and technological changes are more fragmented and slower than in other storylines. The B2 scenario family describes a world in which the emphasis is on local solutions to economic, social, and environmental sustainability. It is a world with continuously increasing global population at a rate lower than A2, intermediate levels of economic development, and less rapid and more diverse technological change than in the B1 and A1 storylines. While the scenario is also oriented toward environmental protection and social equity, it focuses on local and regional levels. Carbon dioxide levels have been projected to increase to $611 \mathrm{ppm}$ for B2 and to 836ppm for A2 by 2100 (IPCC, 2007).

Future climate change is subject to a large degree of uncertainty. Predictions are difficult due to the high complexity and interrelations of the influencing factors and feedback mechanisms. SRES A2 and B2 scenarios were selected for this study, because they represent regional emphasis with either economic or environmental emphasis which might be suitable for Zimbabwe. Scenarios A2b is one of the additional ensemble experiments for A2 scenario (A2a, A2b and A2c). The ensemble members differ in the initial condition of the climate system, and predicted global average temperature changes are similar. There are pronounced differences in projected regional temperature and precipitation.

Due to computational constraints and input data availability, GCMs typically have large spatial resolution and each grid covers wide areas (e.g. HadCM3, $2.5^{\circ} \times 3.75^{\circ}$, latitude by longitude). HadCM3 outputs were used to derive change factors which were applied to a smaller scale historical baseline database in order to obtain future projections. A summary of the methodology is shown in Fig. 3.

Gridded future projection datasets for each time slice were then used to calculate reference ET $\left(\mathrm{ET}_{0}\right)$ for the corn growing season in the study area using the Penman-Monteith equation for each grid pixel. Mean temperature, solar radiation, wind speed and relative humidity were the input parameters for the ETo calculation. 152 IWMI grid pixels covered the study area.

\section{Modeling and mapping IWR}

Net IWR can be defined as the depth of water applied in addition to effective rainfall to meet water loss through ET of a disease-free crop, growing in large fields under non restricting soil conditions and achieving full production potential under the given growing environment excluding conveyance deep percolation water losses. Effective rainfall can be defined as the portion of total rainfall which is used directly in the corn field i.e. total rainfall minus losses due to surface runoff and deep percolation. A spreadsheet model developed to replicate the CROPWAT methodology was used to compute the net IWR for 152 gridded points. A 150-day growth period was used with October $15^{\text {th }}$ as the planting date and March $15^{\text {th }}$ as the harvesting date. Growth stages for the initial, crop development, mid-season and late season were taken as 20, 45, 50 and 35 days respectively (Savvy and Frenken, 2002). 
The United States Department of Agriculture Soil Conservation Service (USDA-SCS) method is used to estimate effective rainfall in this study and shows similar results to observed values. (Moyo and Hagmann, 1994).

$P_{\text {eff }}=P_{t o t} \times\left(125-0.2 \times P_{t o t}\right) / 125$ for $P_{t o t}<250 \mathrm{~mm} / \mathrm{month}$

$P_{\text {eff }}=125+0.1 \times P_{t o t}$

for $P_{t o t}>250 \mathrm{~mm} /$ month

where $P_{\text {eff }}$ is the effective rainfall $(\mathrm{mm})$ and $P_{\text {tot }}$ is the total monthly rainfall.

The crop ET and the net IWR was calculated as

$$
E T_{\text {crop }}=K_{c} \times E T_{o}
$$

$$
\text { Net } I W R=E T_{\text {crop }}-P_{\text {eff }}
$$

where $K_{c}$ is the crop coefficient and Net IWR is the net irrigation water requirement.

Using the IWMI baseline and change factor adjusted projections for the 30 year periods, the net IWR for each grid pixel in the study area was estimated for scenarios A2b and B2a. A gridded dataset was processed by a GIS and a series of maps were generated showing the spatial variation in precipitation and IWR for the baseline and each future scenario.

\section{RESULTS AND DISCUSSION}

\section{Potential changes in agro-climate}

Table 1 shows the estimated rainfall during the growing season for the baseline and future scenarios in the major corn-growing areas of the three provinces. Average rainfall decreases by $13 \%$ (2020s A2b), $6 \%$ (2020s B2a), $15 \%$ (2050s A2b), $1 \%$ (2080s A2b), 2 \% (2080s B2a) and increases by $7 \%$ (2050s B2a) in comparison to a 30 year baseline average of $765 \mathrm{~mm}$. However effective rainfall changes by 5 to $11 \%$ because as the rainfall increases, the effective rainfall ratio decreases. Despite the average decline in the 2020s (A2b and B2a) and 2050s (A2b), rainfall increases again in the 2050s (B2a) and 2080s (B2a and A2b). The spatial variation of rainfall in the study area during the

Table 1 Projected total rainfall for the growing season (October to March) for the future scenarios (unit: $\mathrm{mm})$

\begin{tabular}{c|c|c|c|c|c|c|c}
\hline $\begin{array}{c}\text { Province } \\
\text { (Symbol in Fig. 1) }\end{array}$ & Baseline & $\begin{array}{c}\text { 2020s } \\
\text { A2b }\end{array}$ & $\begin{array}{c}\text { 2020s } \\
\text { B2a }\end{array}$ & $\begin{array}{c}\text { 2050s } \\
\text { A2b }\end{array}$ & $\begin{array}{c}\text { 2050s } \\
\text { B2a }\end{array}$ & $\begin{array}{c}\text { 2080s } \\
\text { A2b }\end{array}$ & $\begin{array}{c}\text { 2080s } \\
\text { B2a }\end{array}$ \\
\hline \hline Mash west (A) & 742 & 643 & 698 & 631 & 794 & 737 & 727 \\
\hline Mash Central (B) & 795 & 689 & 748 & 676 & 851 & 790 & 780 \\
\hline Mash East (C) & 761 & 659 & 716 & 647 & 815 & 756 & 746 \\
\hline Mean & 762 & 660 & 716 & 648 & 815 & 756 & 747 \\
\hline
\end{tabular}

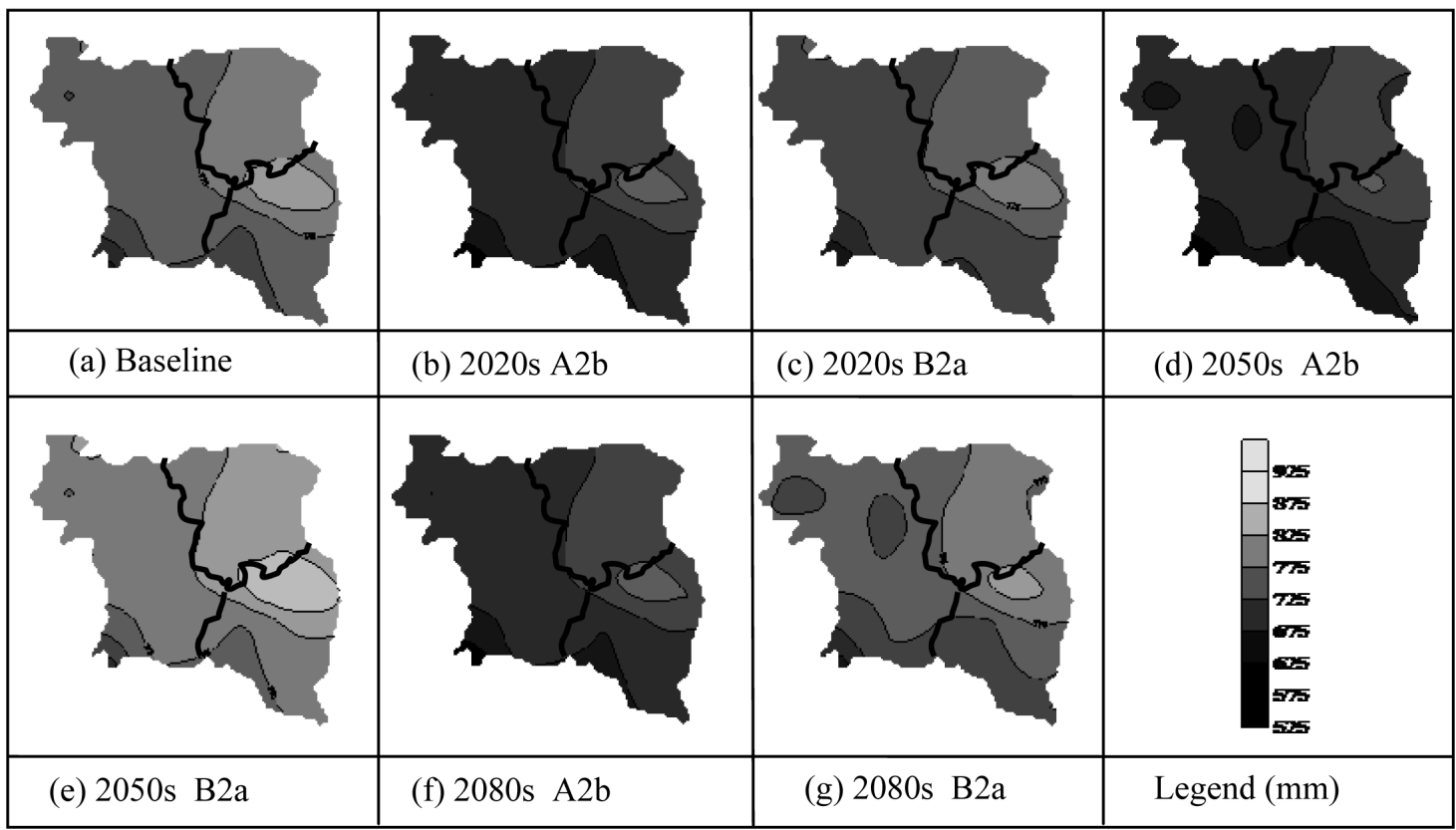

Fig. 4 Spatial variation in mean seasonal rainfall (October to March) for the baseline and future scenarios 
growing season (October to March) for the baseline and future scenarios is shown in Fig. 4. The mean annual temperature averaged across the study region was $19.8^{\circ} \mathrm{C}$ for the baseline period and projected to increase by $1.7^{\circ} \mathrm{C}$ (2020s A2b), $1.6{ }^{\circ} \mathrm{C}$ (2020s B2a), $3.3{ }^{\circ} \mathrm{C}$ (2050s A2b), 2.2 ${ }^{\circ} \mathrm{C}$ (2050s B2a), $5.3{ }^{\circ} \mathrm{C}$ (2080s A2b) and $4{ }^{\circ} \mathrm{C}$ (2080s B2a). The analysis reveals that in all scenarios, temperature has an increasing trend.

For rainfall, the 2 scenarios give different predictions. For the A2b scenario, rainfall will decrease significantly in the 2020s but slowly approach baseline values by the 2080s. For the B2a scenario, however, rainfall is set to decrease in the 2020s but rise above baseline values for the 2050s and slowly decrease to near baseline values by the 2080s. Mashonaland Central has the highest rainfall followed by
Mashonaland East and lastly Mashonaland West.

Precipitation variations are strongly influenced by vertical movement of air due to atmospheric instabilities of various kinds and by the flow of air over orographic features. For models to accurately simulate the seasonally varying pattern of precipitation, they must correctly simulate a number of processes that are difficult to evaluate at a global scale. Many models therefore individually display substantial precipitation biases. Biases can be attributed to errors in the sea surface temperature field of the ocean-atmosphere coupled model, and failure of models to capture the regional rainfall patterns. The inaccuracy of predicted rainfall by the GCM is carried over to the downscaled rainfall predictions. Therefore, the large differences between the A2b and B2a rainfall predictions in the 2050s can be attributed to the

Table 2 Projected corn net IWR for the future scenarios by province (unit: $\mathrm{mm}$ )

\begin{tabular}{|c|c|c|c|c|c|c|c|}
\hline \multirow{2}{*}{ Province } & \multirow{2}{*}{ Baseline } & 2020s A2b & 2020s B2a & 2050s A2b & 2050s B2a & 2080s A2b & 2080s B2a \\
\hline & & (\% change) & (\% change) & (\% change) & (\% change) & (\% change) & ( $\%$ change) \\
\hline Mash West & 171 & $\begin{array}{l}280 \\
(64)\end{array}$ & $\begin{array}{l}251 \\
(47)\end{array}$ & $\begin{array}{l}334 \\
(96)\end{array}$ & $\begin{array}{l}214 \\
(25)\end{array}$ & $\begin{array}{c}346 \\
(103)\end{array}$ & $\begin{array}{l}312 \\
(83)\end{array}$ \\
\hline Mash Central & 140 & $\begin{array}{l}243 \\
(74)\end{array}$ & $\begin{array}{l}215 \\
(54)\end{array}$ & $\begin{array}{c}293 \\
(110)\end{array}$ & $\begin{array}{l}181 \\
(29) \\
\end{array}$ & $\begin{array}{c}303 \\
(117)\end{array}$ & $\begin{array}{l}272 \\
(94)\end{array}$ \\
\hline Mash East & 123 & $\begin{array}{l}234 \\
(89)\end{array}$ & $\begin{array}{l}203 \\
(65)\end{array}$ & $\begin{array}{c}287 \\
(133)\end{array}$ & $\begin{array}{l}165 \\
(33)\end{array}$ & $\begin{array}{l}297 \\
(41)\end{array}$ & $\begin{array}{c}264 \\
(114)\end{array}$ \\
\hline Mean & 149 & $\begin{array}{l}257 \\
(73)\end{array}$ & $\begin{array}{l}228 \\
\text { (53) }\end{array}$ & $\begin{array}{c}310 \\
(108)\end{array}$ & $\begin{array}{l}191 \\
(28)\end{array}$ & $\begin{array}{c}321 \\
(115)\end{array}$ & $\begin{array}{l}288 \\
(93)\end{array}$ \\
\hline
\end{tabular}

\begin{tabular}{|l|l|l|l|}
\hline & (b) 2020s A2b & (c) 2020s B2a & (d) 2050s A2b \\
\hline (a) Baseline & &
\end{tabular}

Fig. 5 Spatial variation in seasonal net irrigation water requirements for the baseline and future scenarios 
lower confidence in rainfall predictions of the GCM.

\section{Corn net IWR}

The long term average $\mathrm{ET}_{0}$ is projected to increase by 10 \% (2020s A2b), 9 \% (2020s B2a), $17 \%$ (2050s A2b), $10 \%$ (2050s B2a), 27 \% (2080s A2b) and $21 \%$ (2080s B2a) from the baseline value of $720 \mathrm{~mm}$. The IWR is projected to increase by $73 \%$ (2020s A2b), $53 \%$ (2020s B2a), $108 \%$ (2050s A2b), 28 \% (2050s B2a), $115 \%$ (2080s A2b) and 93 $\%$ (2080s B2a) compared to the baseline value of $149 \mathrm{~mm}$ as shown in Table 2. Both crop ET and IWR show increasing trends in line with temperature increases. Fig. 5 shows the spatial variation of the net IWR for each scenario and time slice.

For all future time periods, the net IWR shows an increasing trend. Despite projections that rainfall will increase by $7 \%$ in the 2050s for the B2a scenario, the net irrigation water requirement was still greater than the baseline. This is due to that the temperature and radiation increase have a higher effect on IWR than the rainfall increase. A similar trend was demonstrated by Chung (2009b) in a sensitivity analysis of parameters that affect ET and in turn IWR. Mashonaland East has the least irrigation water requirement because it experiences lower temperatures than the other provinces and hence significantly lower ET. Increases in net IWR are higher for the A2b scenario than for the B2a scenario. This arises from the differences in the two storylines. A2 family scenarios project higher carbon dioxide emissions, which will have higher temperature and then ET than B2 family scenarios.

\section{Monthly variations}

The monthly values are just as important as the total seasonal values because water stress in corn varies significantly with growth stages e.g. emergence, vegetative, flowering, grain filling and maturity. Fig. 6 compares the

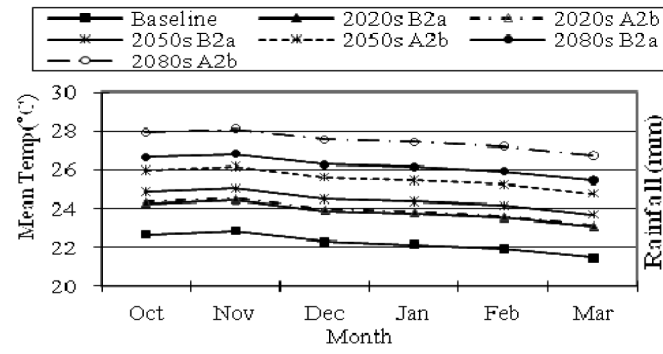

(a) Mean Temperature

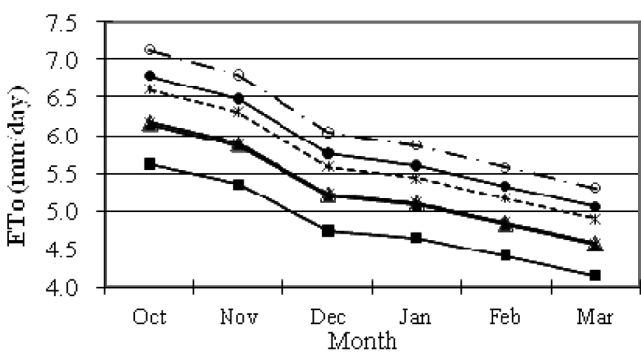

(c) Reference Evapotanspiranon

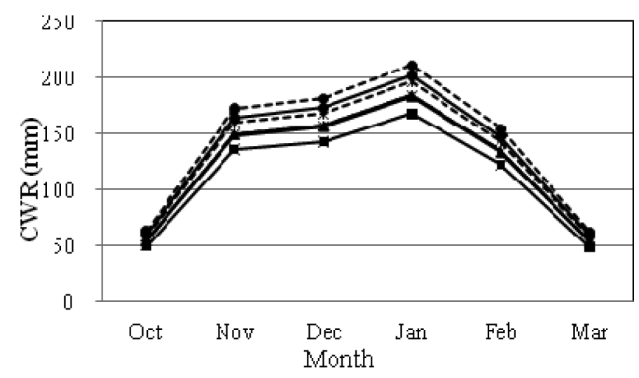

(c) Monthly crop water requirement

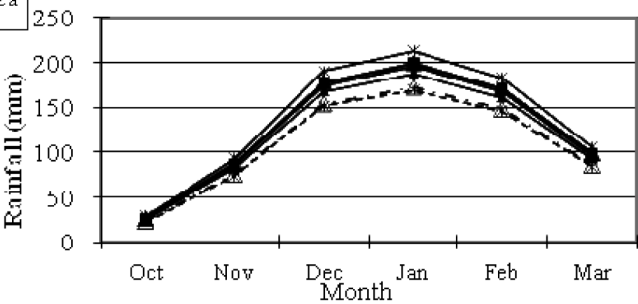

(b) Rainfall

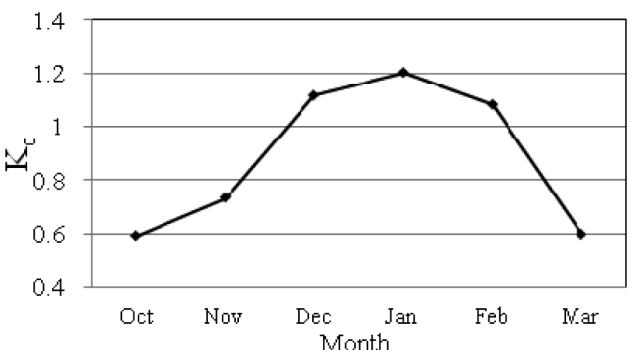

(d) Crop coefficient $\left(\mathrm{K}_{\mathrm{c}}\right)$

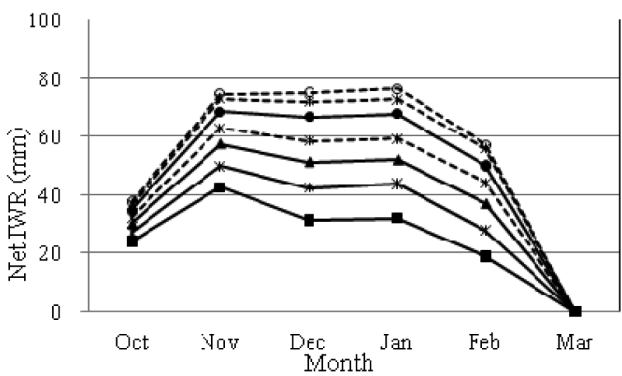

(f) Net Irrigation Water requirement

Fig. 6 Monthly weather parameters and irrigation water requirements for the baseline and future scenarios. 
projected monthly mean temperature, rainfall, ETo, Kc, Crop water requirement (CWR) and net IWR for the baseline and future scenarios. The seasonal average temperature was $22.2^{\circ} \mathrm{C}$ and will increase for all future scenarios. The ETo increases in line with temperature because the energy available for ET i.e. net radiation increases. The rainfall will affect net radiation and then ETo. In Fig. 6 (b) the rainfalls in January are about $100 \mathrm{~mm}$ larger than in March. However, the effect of the rainfall amount is not large compared with that of the high temperature in January.

The high net IWR in November can be attributed to high temperatures and low rainfall. In November and December, the plant gradually attains effective ground cover and evaporation becomes constricted and transpiration becomes dominant. In January the crop reaches full ground cover and the $\mathrm{Kc}$ reaches its maximum hence the high irrigation water demand. Irrigation will not be required in March for all scenarios because the effective rainfall was higher than the crop water requirement.

\section{Adaptation strategy}

An adaptation strategy based only on water resources might be to postpone the corn planting day by about a month to utilize the excess rainfall in March, however issues such as temperature, day length and harvest condition would need to be considered. At the national level, the government can plan and implement anticipatory adaptive measures. Increases in dam capacities and numbers will enhance the availability of water in the future. Construction of these dams allows policy makers to establish irrigation projects, which facilitate a shift from subsistence agriculture to a more sustainable agriculture state. Technology of irrigation has to improve as well in order to minimize water costs. Government policy and support for research and development considerably influences the agricultural production sector. Strategic research planning and a well-directed research programs are needed to study crops, and livestock that are more drought tolerant and disease resistant. Sustained research on short-season, high-yield crop varieties and livestock breeds is of paramount importance to adaptation.

In the future, cropland will have to be expanded and agriculture will have to be further intensified on existing cropland, which poses crucial questions on tradeoffs between future land use for agriculture, natural ecosystems and bioenergy plantations (Gerten et al., 2010). Adaptive measures must be planned and implemented in agricultural infrastructure development and further research on mitigatory measures for the climate change impact for the study region is needed.

\section{Methodological limitations}

Predicting global climatic change impacts accurately on the study area remains largely uncertain. One limitation is that HadCM3 model provides a bigger scale to a much smaller scale baseline and interpolation distortions are inevitable. Another limitation is that since change factors are used, range and variability remain unchanged. One can note that even when considering only one driving emission scenario, for almost every region in Africa there is at least one climate model that projects an increase in precipitation and at least one that projects a decrease (Muller, 2009).

Despite climate being a stochastic process and having a predictable component, the random component could magnify the impact of global climate change in this particular region. Rainfall in southern Africa is strongly influenced by the Inter-Tropical Convergence Zone (ITCZ) and in recent years by the El Niño Southern Oscillation (ENSO). The southern African region has high inter-annual climate variability and hence suffers more from water scarcity than comparable regions with a more even climate (Doll, 2002).

Even though direct $\mathrm{CO}_{2}$ effects on plant physiology were not accounted for in this analysis, corn is a C4 plant, so the elevated $\mathrm{CO}_{2}$ effects are indirect to irrigation water requirements due to increased stomatal resistance and reduced transpiration but could interact with yield.

\section{CONCLUSION}

Impacts of climate change on net irrigation water requirements on corn in Zimbabwe have been presented. Proportional changes in precipitation available to plants were projected to vary from $-15 \%$ to $+7 \%$ depending on the time slice. Temperature was projected to increase by 1.6 to $5.3{ }^{\circ} \mathrm{C}$. The overwhelming impact of increased temperatures especially when coupled with decreases in precipitation will cause net irrigation water requirements to increase by 28 to $115 \%$ mainly in November to Feburary. With such increases in the net irrigation demand, additional environmental problems may arise as freshwater resources on current agricultural land may not suffice to sustain a rising national food demand. The high temperatures could 
affect crop development stages such as grain filling. This implies that cropland will have to be expanded in the future and that agriculture will have to be further intensified on existing cropland, which poses crucial questions on tradeoffs between future land use for agriculture, natural ecosystems, bio-energy plantations, agricultural infrastructural development and research. Anticipatory adaptive measures must be planned and implemented in agricultural infrastructure development and further research on mitigatory measures for the climate change impact for the study region is needed.

This research was supported by Basic Science Research Program through the National Research Foundation of Korea (NRF) funded by the Ministry of Education, Science and Technology (No. 2010-0007884)

\section{REFERENCES}

1. Ahn, S. R., M. J. Park, G. A. Park and S. J. Kim, 2009. Journal of Korea Water Resources Association 42(1): 33-50 (in Korean).

2. Chung, S. -O., 2009a. Climate change impacts on paddy water irrigation requirement in the Nakdong river basin. Journal of the Korean Society of Agricultural Engineers 51(3): 35-41 (in Korean).

3. Chung, S. -0., 2009b. Prediction of paddy irrigation demand in Nakdong river basin using regional Climate model outputs. Journal of the Korean Society of Agricultural Engineers 51(4): 7-13 (in Korean).

4. Chung, S. -O., J. A. Rodriguez-Diaz, E. K. Weatherhead and J. W Knox, 2010. Climate change impacts on water for irrigating paddy rice in South Korea. Irrigation and drainage doi: 10.1002/ird.559

5. Diaz-Nieto, J., and R. L. Wilby, 2005. A Comparison of statistical downscaling and Climate change factor methods: Impacts on Low flows in the river Thames, United Kingdom. Climate change 69:245-268.

6. Döll, P., 2002. Impact of Climate Change and Variability on Irrigation Requirements: A Global Perspective Climate Change 54: 269-293.

7. Gerten, D., and S. Rost, 2010. Climate change impacts on agricultural water stress and impact mitigation potential. World Development Report. Potsdam Institute for Climate Impact Research (PIK), Germany.

8. Food and Agriculture Organisation (FAO), 2005. AQUASTAT country profile Zimbabwe http://www.fao. org/nr/water/aquastat/countries/zimbabwe/index.stm accessed on 12 August 2010.

9. Gordon, C., C. Cooper, C. A. Senior, H. T. Banks, J. M. Gregory, T. C. Johns, J. F. B. Mitchell and R. A. Wood, 2000. The simulation of SST, sea ice extents and ocean heat transports in a version of the Hadley Centre coupled model without flux adjustments. Climate Dynamics 16: 147-168.

10. IPCC-TGICA, 2007. General Guidelines on the Use of Scenario Data for Climate Impact and Adaptation Assessment. Version 2. Prepared by T.R. Carter on behalf of the Intergovernmental Panel on Climate Change, Task Group on Data and Scenario Support for Impact and Climate Assessment, 66.

11. Moyo, A. and J. Hagmann, 1994. Growth-Effective Rainfall in Maize Production under Different Tillage Systems in Semi-Arid Conditions and Shallow Granitic Sands of Southern Zimbabwe.

12. Müller, C., 2009. Climate Change Impact on Sub-Saharan Africa. An overview and analysis of scenarios and models Discussion Paper/Deutsches Institut für Entwicklungspolitik ISBN 978-3-88985-451-3.

13. Musara, M., M. Chikuvire and M. Moyo, 2010. Determinants of micro irrigation adoption for maize production in smallholder irrigation schemes: case of Hama Mavhaire irrigation scheme, Zimbabwe. African Journal of Food Agriculture and Nutrition Development 10. No.1 Nairobi, Kenya.

14. New, M., D. Lister, M. Hulme and I. Makin, 2002. A high resolution data set of surface climate over global land areas. Climate Research 21: 1-25.

15. Savvy, A. and K. Frenken, 2002. Crop water requirements and irrigation scheduling. Irrigation manual 4 Fontline Electronic Publishing, Harare, Zimbabwe $42-48$.

16. Unganai, L., 1996. Historic and Future Climatic Change in Zimbabwe Climate Research 6: 137-145.

17. Zhakata, B., 2004. Vulnerability and Adaptation of Maize Production to Climate Change in Zimbabwe. Government Publication - Zimbabwe. 